\title{
Societal and economic impacts of flood hazards in Turkey - an overview
}

\author{
Gamze Koç ${ }^{1, a}$ and Annegret H. Thieken ${ }^{1}$ \\ ${ }^{1}$ University of Potsdam, Institute of Earth and Environmental Science, Karl-Liebknecht-Straße 24-25, 14476 Potsdam, Germany
}

\begin{abstract}
Turkey has been severely affected by many natural hazards, in particular earthquakes and floods. Although there is a large body of literature on earthquake hazards and risks in Turkey, comparatively little is known about flood hazards and risks. Therefore, with this study it is aimed to investigate flood patterns, societal and economic impacts of flood hazards in Turkey, as well as providing a comparative overview of the temporal and spatial distribution of flood losses by analysing EM-DAT (Emergency Events Database) and TABB (Turkey Disaster Data Base) databases on disaster losses throughout Turkey for the years 1960-2014. The comparison of these two databases reveals big mismatches of the flood data, e.g. the reported number of events, number of affected people and economic loss, differ dramatically. With this paper, it has been explored reasons for mismatches. Biases and fallacies for loss data in the two databases has been discussed as well. Since loss data collection is gaining more and more attention, e.g. in the Sendai Framework for Disaster Risk Reduction 2015-2030 (SFDRR), the study could offer a base-work for developing guidelines and procedures on how to standardize loss databases and implement across the other hazard events, as well as substantial insights for flood risk mitigation and adaptation studies in Turkey and will offer valuable insights for other (European) countries.
\end{abstract}

\section{Introduction}

Even if natural events are a part of the Earth's system, extreme events can have destructive power and cause tremendously impact human society. Especially over the last two decades, natural hazards have caused enormous human and economic losses in Turkey that occasionally amounted to 3 to $4 \%$ of the gross national product [1]. Turkey is severely affected by many perils owing to its climatic, tectonic, topographic and seismic properties. Although disasters such as floods, landslides and wildfires are common in Turkey, earthquakes take the first place when evaluated in terms of their devastating effects.

While there are numerous studies and a large body of literature on earthquake hazards and risks in Turkey, relatively little is known about flood hazards and risks.

Between the years 1955 and 2009, 2089 flood disasters have been listed, and for the years 1960 to 2009 , 1919 events are reported which caused 1050 fatalities, 3.1 billion US\$ economic loss and 1.9 million ha flooded area [2]. It has been indicated that $52 \%$ of all flood events occurred in Black Sea, Mediterranean and Marmara region [3]. Other studies about flood events in Turkey show that Black Sea, Eastern Anatolia and Mediterranean region respectively had higher flood risk [2] and the most of the human deaths due to floods occurred in Black Sea and Eastern Black Sea basin [4]. The areal distribution of flood events shows that Black Sea Region, Eastern Anatolia and Mediterranean Sea Region had higher frequency of flood events. However, although the Eastern Black Sea Region had a comparatively little number of flood events, these events had more destructive effects than in the other regions [2]. To provide an overview of the spatial and temporal distribution of floods events in 2007 in Turkey, 237 principle climatological stations records had been used and between 1940 and 2005 it has been reported 1768 flood events by which 1344 people

\footnotetext{
${ }^{a}$ Corresponding author: Gamze.Koc@uni-potsdam.de
}

died [5]. According to information of 1768 flood events, seventeen major flood events and losses have been listed. The spatial distribution of flood events shows that, the occurrence of events does not distribute uniformly. Congruently, valleys in Black Sea, the Marmara and Aegean Region are under threat in particular $([3,5,6$, $7,8,9]$ ). For the western part of the Turkey, heavy rainfall with combination of geomorphological features plays a main role for flood events. And for the flood events in Central Anatolia Region and eastern part of the Turkey, snow accumulation and sudden snowmelt is the main reason [5]. Another similar study for an overview relevant the flood events had been approached to natural hazards considering number of damaged buildings and number of affected provinces in the period 1960 to1975. Although the total number of events is not mentioned, it is reported that 945 provinces and 24582 buildings were damaged between 1960 and 1975 [10]. These literature examples show that flood damage data differ from source to source based on institutions and each organization enrols different indicators according to their requirements or areas of interest. Therefore, this paper focusses on providing an overview of flood hazards in Turkey while reflecting on the suitability of different disaster data bases to fulfil this task.

In general, data on disaster events and their impacts are scarce in comparison to other scientific fields in natural hazard research, although the lack of reliable, consistent and comparable data is seen as a major obstacle for effective and long-term loss prevention. To improve the comparability of current loss databases, hazards must be standardized by a common classification [11]. Currently, only a few data sets, in particular the emergency events database EM-DAT [12] hosted and maintained by the Centre for Research on the Epidemiology of Disasters (CRED) since 1988, are publicly accessible and have become widely used to 
describe trends in disaster losses. However, loss data are subjected to various biases. To eliminate these biases and to provide high quality loss data to decision makers, the public, the planners, the scientists or the other end users, it is recommended to standardize some key areas related to loss data collection [13]. Since Turkey is in the favourable position of having a distinct national disaster database since 2009, i.e. the Turkey Disaster Data Base (TABB), there is the unique opportunity to investigate flood impacts in Turkey in more detail as well as to identify biases and underlying reasons for mismatches with EM-DAT. Therefore, Turkey was selected as study area to provide an overview of flood patterns, spatial \& temporal distribution of flood events, societal and economic impacts of flood hazards by comparison of two databases. It is aimed to discuss how to standardize and develop loss databases for flood hazards in Turkey by discussing mismatches between EM-DAT and TABB as well. Since loss data collection is gaining more and more attention, e.g. in the Sendai Framework for Disaster Risk Reduction 2015-2030 (SFDRR) [28] and the loss and damage program of the UNFCCC (United Nations Framework Convention on Climate Change), the study could offer a base-work for developing guidelines and procedures on how to standardize loss databases and implement across the other hazard events, in order to monitor developments in event frequencies as well as (flood) risk mitigation and adaptation studies in Turkey.

\section{Databases}

\subsection{EM-DAT (Emergency Events Database)}

EM-DAT (Emergency Events Database) is one the most frequently used global and publicly accessible database on both technological and natural disasters in the world. Initially supported by WHO (World Health Organization) and the Belgian Government, EM-DAT has been maintained and hosted since 1988 by the Centre for Research on the Epidemiology of Disasters (CRED). EM-DAT's main objective is to provide information relevant for humanitarian aid at national and international levels. It is further aimed to rationalise decision making for disaster preparedness and to provide data for vulnerability assessments. EM-DAT contains essential data on the occurrence and impacts of more than 21000 damaging events from all over the world from 1900 to present. Various sources, including UN agencies, nongovernmental organisations, insurance companies, research institutes and press agencies are used to fill the database [12]. EM-DAT classifies disasters based on the IRDR peril classification and hazard glossary [11]. It describes an event by five levels of peril classifications (disaster group, disaster sub-group, disaster type, and disaster sub-type and disaster sub-sub-type). In EMDAT, it is possible to retrieve data by selection criteria (e.g. time period, location, disaster classification). However, an event is only included in EM-DAT if it fulfils one of the EM-DAT criteria (Table 1). Information on total deaths, number of injured people, number of affected people, number of homeless people, total affected and total damage in ' 000 US\$ are provided by EM-DAT as well.

\subsection{TABB (Turkey Disaster Data Base)}

In 1999, Turkey experienced a serious damaging event in the Marmara region. Because of the big Marmara earthquake, 18373 people lost their lives [14], 43953 people had been affected [15] and up to $\$ 6.5$ billion economic loss [16] occurred. After the Marmara earthquake, the collection of disaster losses for reducing the impacts of the disasters and for risk management studies became an important issue in Turkey. Therefore, the National Earthquake Investing Program (UDAP) was developed by the Republic of Turkey Prime Ministry Disaster and Emergency Management Authority (AFAD) in 2011 [17]. Turkey Disaster Database (TABB) has been developed within the UDAP project in order to supply all corresponding documents and sources (e.g. dissertations, reports, books, photos, videos) about both natural and anthropogenic disasters experienced so far. With this project, it is aimed to support the disaster preparedness and risk mitigation studies by presenting all documents and data that have been prepared by universities, local administrations, state institutions and organizations and non-governmental organisations. Using of the concept of UNDP (United Nations Development Programme) DesInventar database concept, TABB was set-up in 2009 and is now hosted and maintained by AFAD [18].

Initially, a contract with a newsagent ensured that all newspapers between 1900 and 2014 could be used to extract disaster loss information that was also geocoded. An interview with AFAD-representatives in May 2015 revealed that TABB was fundamentally updated in March 2015 and now contains reliable data from 1923 to 2015 . TABB was developed into two modules, which are called as "Document Module" and "Analysis Module" [19]. When users access electronic documents and their sources about disasters by using "Document Module", they can perform statistical analyses. Data download as.doc, .xls or .pdf formats is possible by using the "Analysis Module". All events, for which an "AFAD information card" that is used in the Turkish emergency management exists, are included in TABB. TABB is also publicly accessible like EM-DAT. But in contrast to EMDAT, there are no thresholds or entry criteria such as a certain number of dead or affected people (Table 1).

\subsection{A Comparative Overview: EM-DAT vs. TABB}

\subsubsection{Pre-processing of TABB}

Since most of the studies focus on the economic and societal impacts in a region based on global databases (e.g. EM-DAT) [20], it is comparatively easy to reach economic and societal loss data. However, global databases do not always reflect the spatial-temporal dynamics of events. Regional databases could have more detailed information and could be useful for regional studies on damage assessment. 


\begin{tabular}{|c|c|c|}
\hline & EMDAT & TABB \\
\hline Spatial coverage & Global & National \\
\hline Spatial resolution & Country & Regional \\
\hline Parameters & $\begin{array}{l}\text { Injuries, fatalities, affected, } \\
\text { homeless, insured damages, } \\
\text { reconstruction costs, total } \\
\text { damages }\end{array}$ & *Please see Annex 1 \\
\hline Time interval & 1900-present & 1923-present \\
\hline Update interval & Every 3 months & Irregular intervals \\
\hline Thresholds & $\begin{array}{l}\geq 10 \text { fatalities } \\
\geq 100 \text { affected } \\
\text { Declaration of state of emergency } \\
\text { Call for international assistance }\end{array}$ & No thresholds \\
\hline Data Accessibility & Downloadable (.xls) & $\begin{array}{l}\text { Downloadable(.xls, .doc, .pdf), (singly for } \\
\text { each hazard type) }\end{array}$ \\
\hline User Access & Public & Public \\
\hline Sources & $\begin{array}{l}\text { United Nations, National } \\
\text { Governments, US Governments, } \\
\text { NGO's, Inter-Governmental } \\
\text { Organizations, Reinsurance } \\
\text { Companies, Press, etc. }\end{array}$ & $\begin{array}{l}\text { Universities, local administrations, state } \\
\text { institutions \& organizations, non- } \\
\text { governmental organizations, news } \\
\text { agencies }\end{array}$ \\
\hline Priority Source & UN agencies & News agencies \\
\hline Host institution(s) & $\begin{array}{l}\text { Center for Research on the } \\
\text { Epidemiology of Disaster, Catholic } \\
\text { University of Louvain }\end{array}$ & $\begin{array}{l}\text { Republic of Turkey Prime Ministry Disaster } \\
\text { \& Emergency Management Authority }\end{array}$ \\
\hline Web-page: & www.emdat.be & tabb.afad.gov.tr \\
\hline
\end{tabular}

Table 1. Comparative summary of EMDAT \& TABB

TABB is the only regional and publicly accessible disaster database for Turkey. Though, due to a lack of standardization and classification, all information about the disasters in database is unsorted. To make TABB more organized and comparable with EM-DAT, the events were reclassified. For natural disasters, the IRDR peril classification system [11] that was proposed by a workgroup within the Integrated Research on Disaster Risk (IRDR) was used. For anthropogenic disasters, a combined classification system has been created (Figure
1) by adapting both EM-DAT technological disaster classification and literature sources [21].

All disasters in TABB were assigned to a disaster generic group, a disaster sub-group, a main disaster type, a sub-disaster type and a sub-sub disaster type name by using a united disaster classification system. After the reclassification, TABB has become comparable with EMDAT in terms of structure. For the analyses, the period from 1960 to 2014 was selected to procure a minimum timeframe of 50 years. For the concurred time slot, 
accessibility of the hydro-meteorological data for the further studies was considered as well.

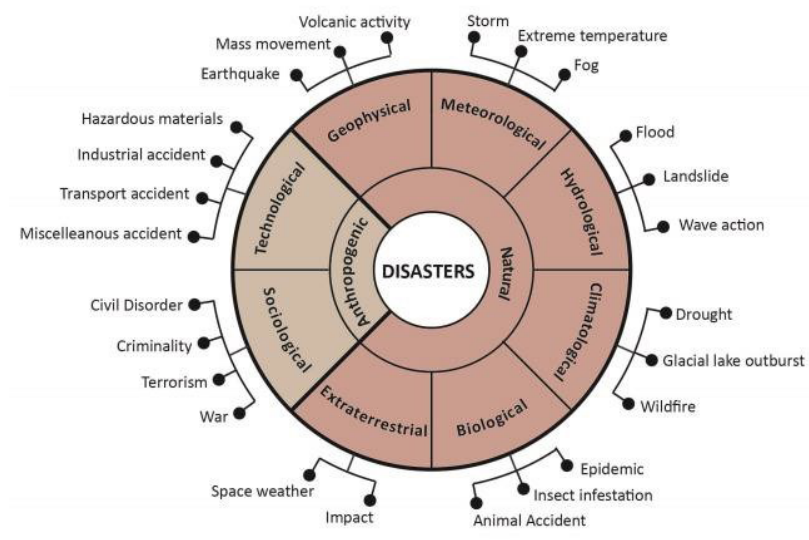

Figure 1. United disaster classification system

\subsubsection{Overview of hazards in Turkey}

In the last fifty years, Turkey has experienced numerous natural hazards. Between 1960 and 2014, EMDAT (as at June 2015) reports 269 hazards -136 anthropogenic hazards and 133 natural hazards- in total. According to EM-DAT, geophysical hazards take the first place in the list with $42.1 \%$ of those natural hazards and hydrological hazards are the second most frequent hazards with $35.3 \%$ quantile. For the same time interval, TABB (as at June 2015) has listed $18208^{\mathrm{a}}$ hazards in consisting of 5219 anthropogenic hazards and 12988 natural hazards. In contradiction to EM-DAT, meteorological hazards are the most frequent hazards in the database (31.8\% of all hazards) and hydrological hazards are the third frequent hazard type in the list (21.4 $\%$ ) on the basis of the number of events (Figure 2). In the TABB database, 181 erosion and two geo-medical events were also listed. Since these sub-sub disaster types do not exist in the IRDR peril classification system, they were listed under the category "Other".

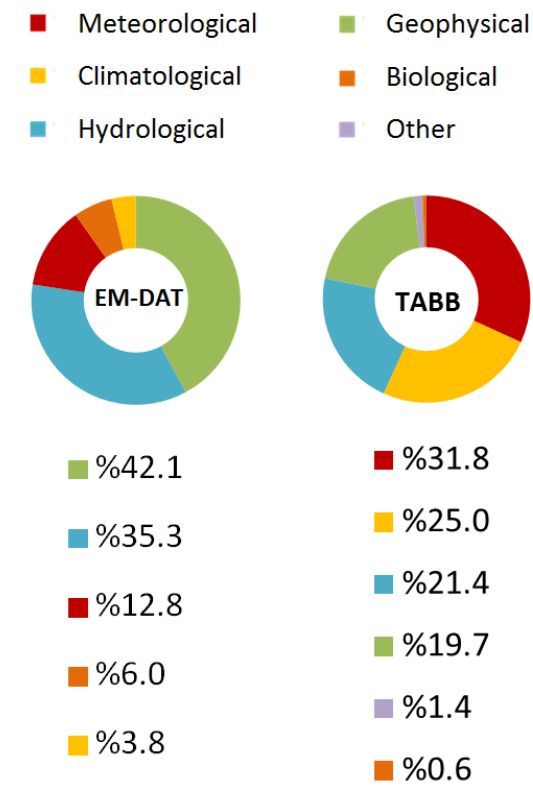

Figure 2. Percentile of natural disaster sub-groups in Turkey (1960-2014)

When analysing event frequencies based on the disaster main types, wildfire is the most frequent hazard (2586 wildfire events, $19.9 \%$ of all natural hazards) in Turkey according to TABB (Figure 3). Flood hazards (1076 flood hazards, $8.3 \%$ of all natural hazards) take the sixth place in the list after storms (2364 storm event), earthquakes (2004 earthquake events), landslides (1702 landslide events) and extreme temperature (1647 extreme temperature events). When fatalities are considered in the TABB database, earthquakes are the most destructive hazards in Turkey that caused 75904 fatalities between the years 1960-2014. Flood hazards are the third destructive hazards -by which 795 people died- after extreme temperature hazards (with $60222^{\mathrm{b}}$ fatalities).

\section{Overview of Natural Hazards in Turkey (1960-2014)}

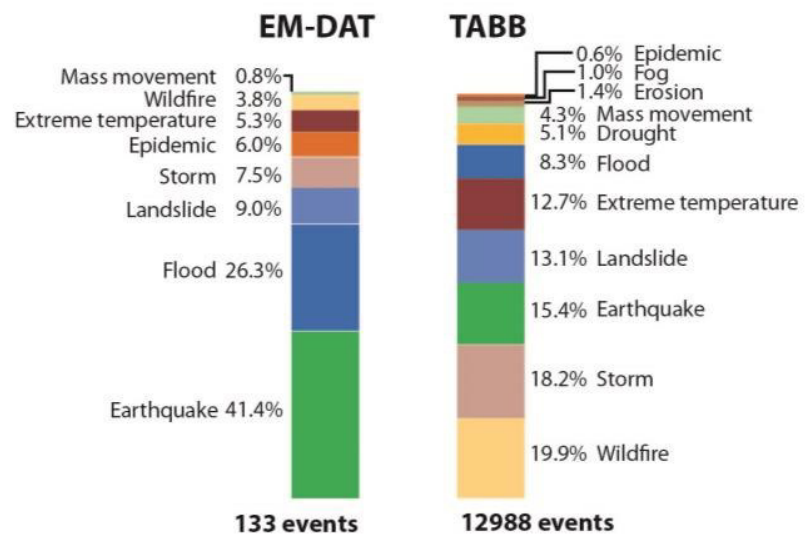

Figure 3. Overview of natural hazards in Turkey based on disaster main types (1960-2014)

\footnotetext{
${ }^{\mathrm{a}}$ In TABB database there is also one Famine event has been listed. But since there is not detailed information in explanations part related to reason (anthropogenic; e.g. war or natural; e.g. extreme temperature, drought) of Famine, this event has not been included in classification.
}

\footnotetext{
${ }^{b}$ The detailed information and data conflicts in number of events with the current version of TABB have been discussed in Conclusion \& Implications part.
} 
As the EM-DAT database applies thresholds (Table 1), the number of events differs greatly from the data given by TABB. EM-DAT contains substantially fewer records for Turkey. For the period from 1960 to 2014, EM-DAT reports 55 earthquake events $(41.4 \%$ of all natural hazards) which are here the most frequent hazard type in Turkey, while flood events takes the second place in the list with 35 events (26.3\% of all natural hazards). In line with number of events, earthquakes have been reported as most destructive hazard types in Turkey by which caused 32256 fatalities and the floods are the second destructive hazard with a death toll of 773 .

Figure 5 and Figure 6 show the cumulative distribution of natural hazards' occurrences by years for the databases EM-DAT and TABB from 1960 to 2014. Although their scales differ considerably, the temporal trends of the number of natural hazards are similar. Evolution of information systems in the early 1980s [22] and in parallel with this, the development of loss data collection and storage technologies are regarded as a major source for this effect. Moreover, the spatial distribution of natural hazards has importance to identify disaster-prone regions that are in need of support by disaster management and risk mitigation. While the TABB platform allows users to view the locations of each event on the map as point, unfortunately there is no more information about their impacts. And so, all disasters in TABB have been digitized, geo-referenced, mapped and linked with the TABB loss data as attribute table to make easier to display characteristics of the events as well (Figure 4). Such maps help users to have a general overview of spatial distribution of natural hazards in Turkey based on the number of events.

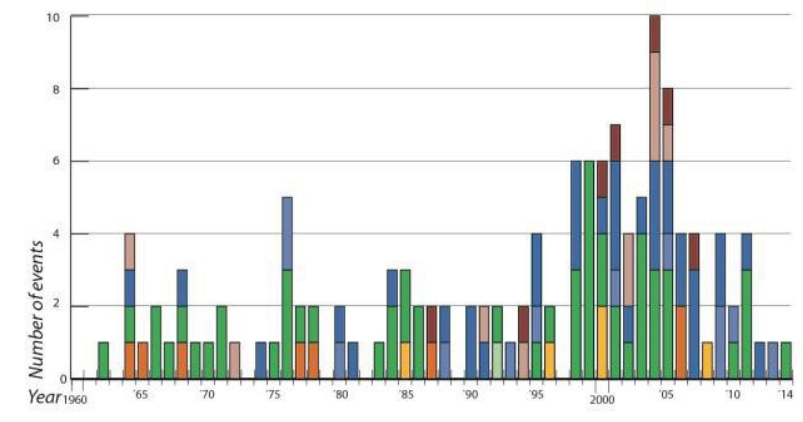

Figure 5. Cumulative distribution of natural hazards' occurrences by years (EM-DAT, 1960-2014)

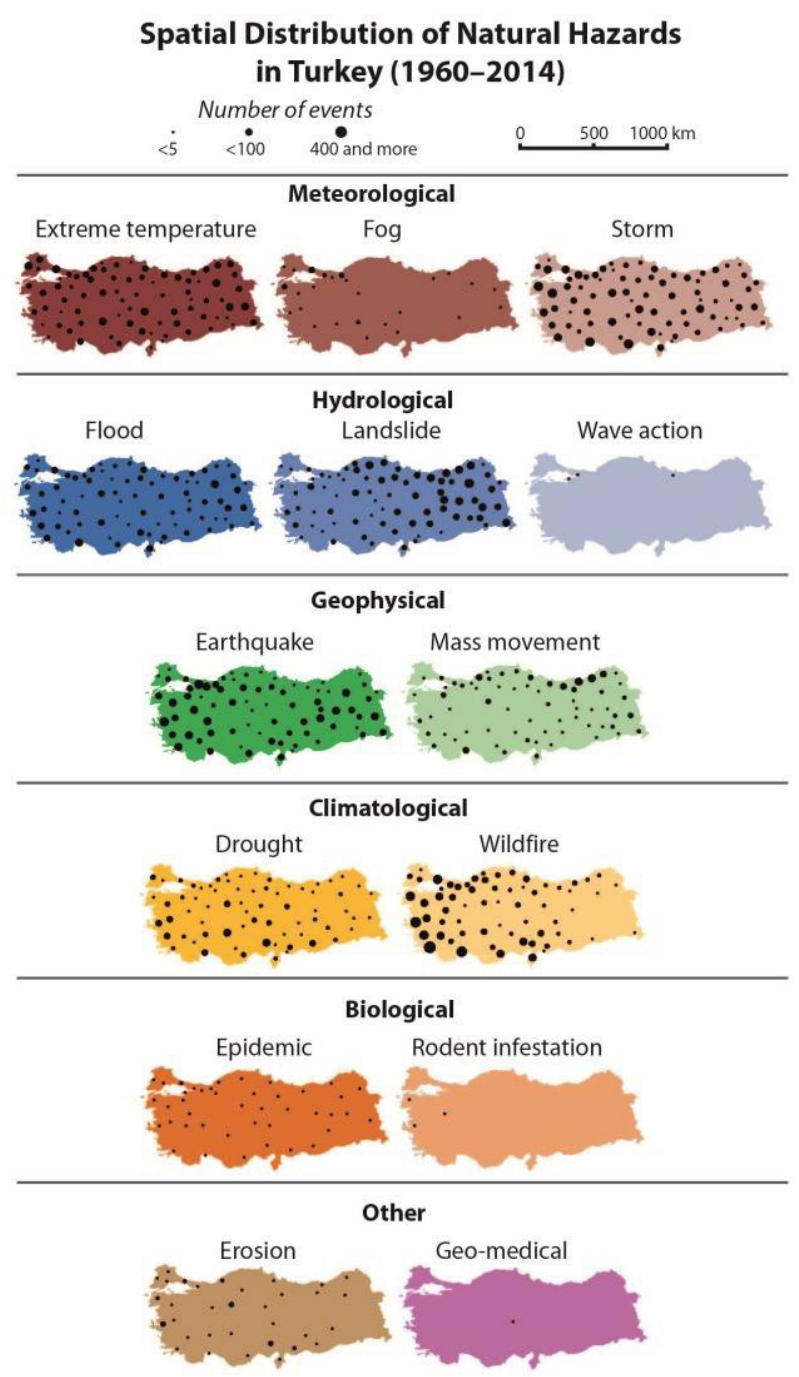

Figure 4. Spatial distribution of natural hazards in Turkey (TABB, 1960-2014)

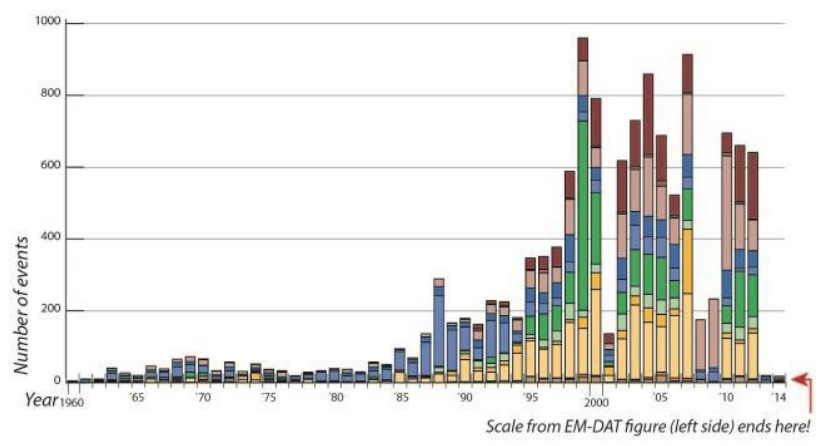

Figure 6. Cumulative distribution of natural hazards' occurrences by years (TABB, 1960-2014) 


\section{Flood Hazards in Turkey}

As outlined above, flood hazards take the third place in natural disasters human loss list in Turkey according to TABB. Floods are due to heavy rainfall on the coastal areas of the western and southern parts of Turkey or to a sudden increase in air temperature, resulting in snow melt in eastern, mountainous part of southeast Turkey, especially Eastern Black Sea region [23].

According to the analysis of the TABB database, Erzurum province -which is located Eastern part of Turkey-, has the most flood events (64 flood events) in Turkey between the years 1960-2014 (see also Fig. 4). Antalya province, that is located in the Mediterranean region, keeps up with Erzurum with 55 flood events and takes the second place in the list. The number of flood events does, however, not imply any human or economic losses. When TABB was analysed with regard to fatalities, it reveals that flood hazards are more destructive in Eastern Black Sea region (Figure 7). Trabzon province has the most fatalities (145 death tolls) due to flood events between 1960 and 2014. Similarly, when $\mathrm{TABB}$ was analysed with respect to economic losses, it could be reported that the Black Sea and Mediterranean regions suffered from the highest economic losses. The biggest economic loss due to flood hazards in the 1960-2014 period occurred in Giresun province, which belongs to the Eastern Black Sea region, with US\$ 7.2 trillion (Figure 8). In view of TABB analyses results, it is possible to interpret that Black Sea and Mediterranean regions are comparatively more prone to flood hazards and risks.

\subsection{Societal and Economic Impacts of Catastrophic Flood events (1960-2014)}

The comparative overview using TABB and EMDAT shows that global or regional databases do not include the same severe events. To better understand the flood regime and pattern, the analysis of catastrophic flood events is a next step. Therefore, a list with the most severe flood events was compiled that serves as a basis for a detailed analysis of flood hazards in Turkey. Catastrophic flood hazards between 1960 and 2014 have been identified using all the data and information that was available in TABB and EM-DAT. In addition, scientific literature, news archives and the Global Active Archive of Large Flood Events - Dartmouth Flood Observatory [29] were used to complement the databases. With this part of the study, it is also aimed to show mismatches in different data sources. For the 1960-2014 time periods, 25 most catastrophic flood events have been listed (Annex 2). To make an overview for societal and economic impacts of these 25 most catastrophic flood events, human loss, economic loss and number of effected people were considered.
Economic losses have been calculated in US\$ by using event days' exchange rates of the Central Bank of the Republic of Turkey (CBRT) ([24, 25]). For this calculation, explanatory notes in TABB, in literature and the information that was obtained from the AFAD representatives during an interview was considered. Considering and comparing all sources of information, it becomes apparent that fatalities, the number of affected people and economic losses differ dramatically. For example, although the Mersin- Adana flood event of December 1968 is the most destructive event in Turkey with 147 fatalities reported in EM-DAT, there is no information neither in TABB, nor in the Dartmouth archive or in the scientific literature. Similarly, the Isparta (Senirkent) flood event of July 1995 is reported as one of the most destructive flood events in terms of fatalities (74 fatalities) in $\mathrm{TABB}$ as well as in case studies in the literature. Surprisingly, this event neither exists in EMDAT nor in the Dartmouth archive. On the other hand, information for some of the flood events is very similar with regard to the number of reported fatalities, the number of affected people or the economic losses - even in different data sources. A flood that hit the Western Black Sea region (Zonguldak, Karabuk, Bartin, Sakarya) in May 1998 was identified as the most devastating event with regard to economic losses. EM-DAT reported 10 fatalities, 1240047 affected people and US\$ 1.0 billion economic loss. Dartmouth reported 19 fatalities and US\$ 2.0 billion economic losses and TABB reported 5 fatalities, 43547 affected people for the same flood event. Case studies about the same flood event mention differing numbers for human and economic losses. Human losses vary from 10 to 27 fatalities and affected people vary 1.2 million to 2.2 million. Finally, the maximum economic loss is given as US\$ 2.0 billion for this flood event.

To see the spatial distribution of most severe flood hazards in Turkey, all events have been digitized; georeferenced and mapped (Figure 9). To make a relation with most severe flood events list (Annex 2, Ref. Nr.), reference numbers have been given to each event and these numbers are displayed in the map (Figure 9). The provinces that were mainly affected by the flood events are also illustrated. According to Figure 9, it is possible to see that most of the catastrophic flood events take place in Eastern Black Sea and the East-southeast Anatolian Mediterranean region. 


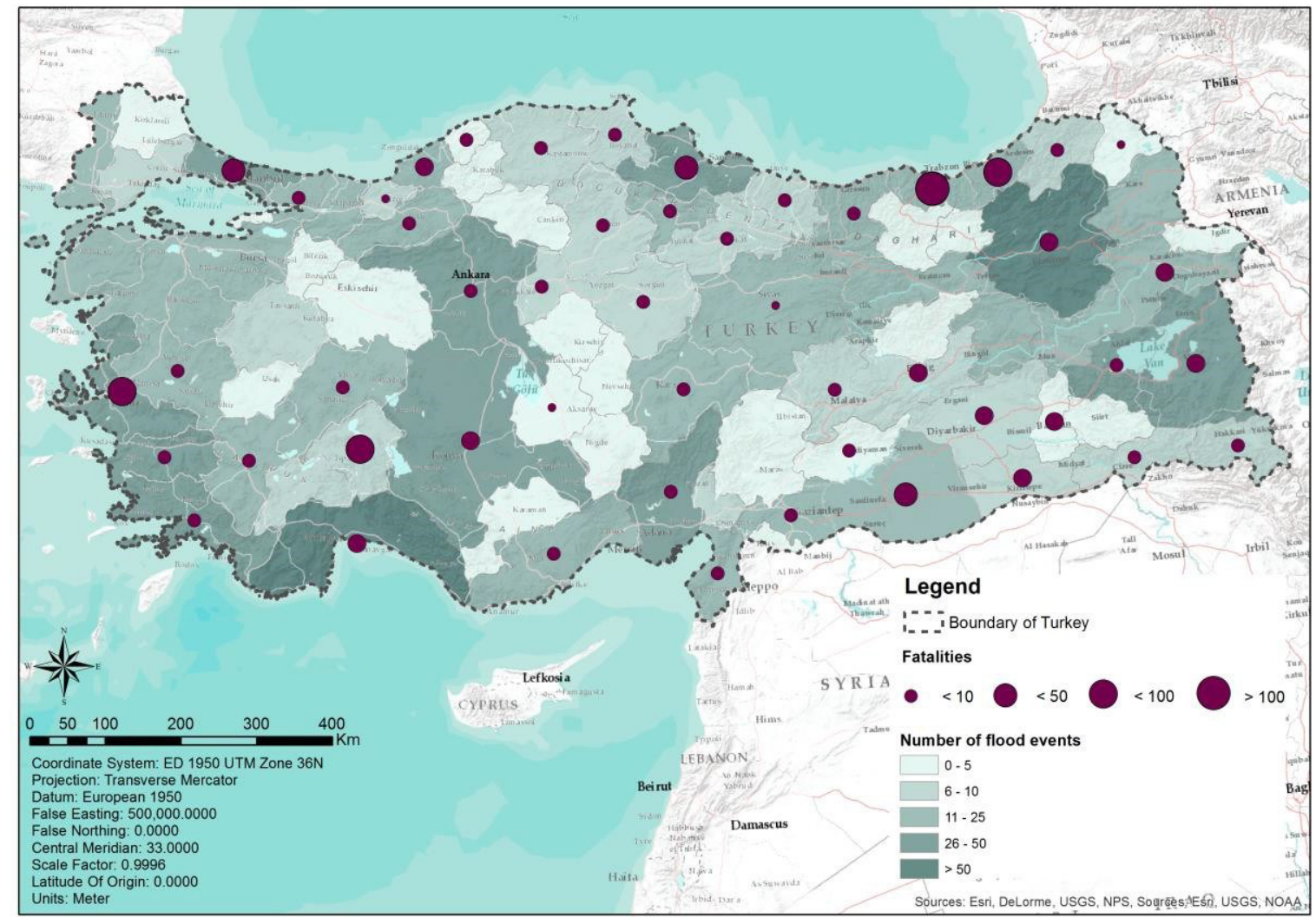

Figure 7. Fatalities due to flood hazards in Turkey (TABB, 1960-2014)

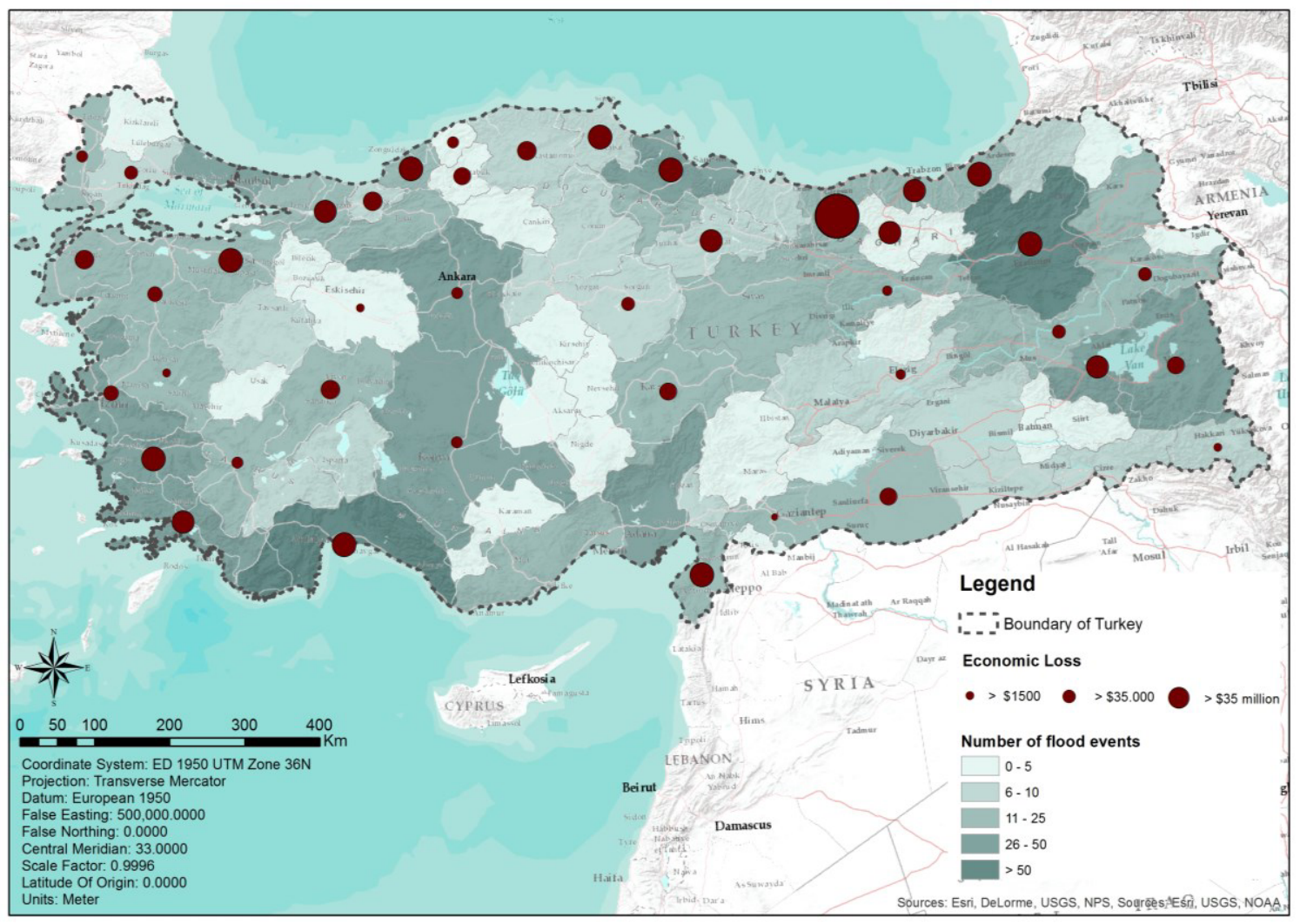

Figure 8.Economic losses due to flood hazards in Turkey (TABB, 1960-2014) 


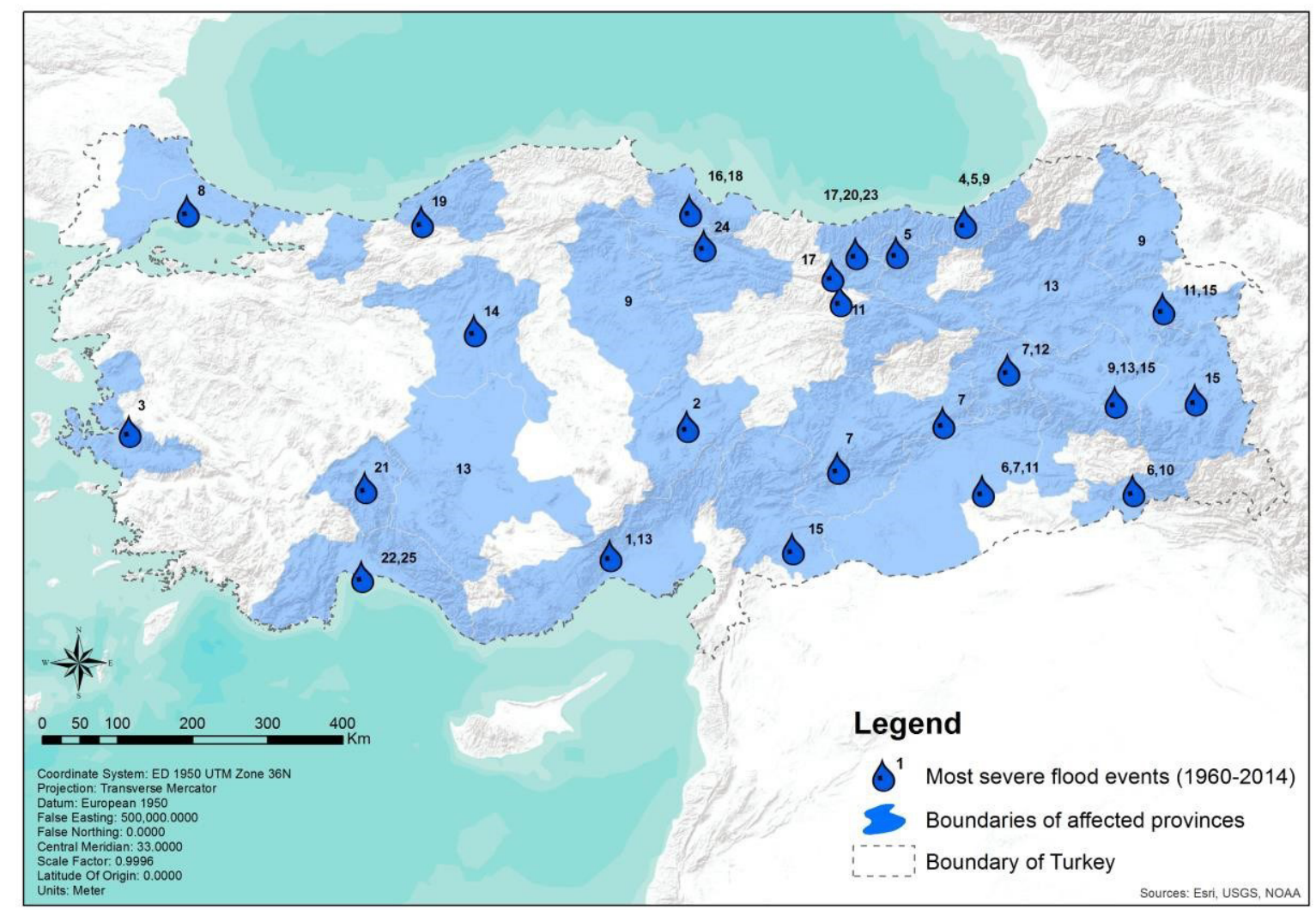

Figure 9. Most severe flood hazards in Turkey (1960-2014)

\section{Conclusion \& Implications}

In this study, an overview of the spatial and temporal distribution of natural hazards, particularly flooding, has been presented for Turkey. Therefore, the TABB database was reclassified and the databases EMDAT and TABB were compared with regard to the number of events, as well as economic and human losses. Finally, the most severe flood events in Turkey were retrieved and interpreted for the years 1960-2014. These events will be used for further studies about the flood triggering processes and risk drivers.

The comparison of the two databases shows that large mismatches between a global and a national database might occur. Current global and national databases for monitoring losses from national hazards suffer from a number of limitations, which in turn could lead to misinterpretations of loss data. These biases include a hazard bias, a temporal bias, a threshold bias, an accounting bias, a geographic bias and a systematic bias [13]. According to comparison of the EM-DAT and $\mathrm{TABB}$, it is possible to see these major biases in loss information. This comparative overview is a good example for temporal bias, threshold bias and accounting bias in particular. Temporal bias infers that, losses are comparable over time [13]. Changes in monetary value in time directly affect the economic losses. In TABB, all economic losses are given in Turkish Lira (TL) denominated and since the changes the monetary value in TL and US\$ are different, it is a fallacy to compare losses over time. Especially, currency unit changes of TL in 2005 , caused confuse the comparing the economic losses.

Another issue about the economic losses given in TABB is missing or untrusted data. When the list of the most severe flood events is interpreted, it seems that there are some non-realistic loss data in TABB (Annex 2, e.g. US\$ 0.004 , US\$ $21.4 \ldots$...). These numbers could be commented as faulty data input or mistake. And at that case, these data shows the lack of data quality and accuracy control in TABB. ${ }^{(b)}$ Similarly, when fatalities were analysed for all natural hazards, extreme temperature hazards caused 60222 fatalities according to TABB and 60000 fatalities had occurred in one event (08.10.1996, extreme temperature (cold wave), KarsSarikamis province, Glide Nr: S-24505f5e-1985, TABB June, 2015). The number of fatalities is not realistic and equal with the then-current population of Sarikamis region [26]. When the current version of TABB is checked (February, 2016), it is possible to see that this extreme temperature event was removed from the database. This case is another example for importance of standardization, accuracy and quality control studies in loss databases.

Another bias in these databases is threshold bias. Threshold bias infers that, all losses, regardless of size are counted [13]. An event is only included in EM-DAT if one of the following criteria is fulfilled: 1)10 or more 
people died in the event; 2)100 or more people were affected by the event; 3) a state emergency was declared or 4) there was a call for international assistance. In contrast with EM-DAT, TABB contains all hazard events without any thresholds (Table 1). Threshold bias has caused fallacy to compare the two different-scaled databases. For instance, Figure 5 and Figure 6 illustrate well how the thresholds affect the content of the databases in term of number of events. Another conspicuous bias in this study is the systematic bias. Systematic bias infers that losses are the same regardless of the database used. Systematic bias starts from initial data collection methods to computing data [13]. EMDAT and TABB obtain the data from various sources (Table 1) and the lack of standardization during data collection and computing processes, fallacies become during database comparison. With this implication, it is aimed to show the current situation of loss data in TABB and EM-DAT with a comparative overview and this study could help the further studies to overcome these problems and biases and to help the development of high quality, reliable and standardized databases for natural hazards.

Accurate accounting for disaster impacts is an important perspective for improving disaster risk management [22]. In disaster management studies, damage assessment of natural hazards play an important role. Especially, the estimation of economic damage of flood hazards is gaining more important in Europe [27]. And historical data allow analysts to search for disaster trends and causal factors over time and regions [22]. Therefore, to supply a useful database for historical severe flood events in Turkey, catastrophic flood events list has been retrieved (Annex 2) and mapped (Figure 9). Furthermore, to show the biases in the flood database, a comparative data list has been presented and data gaps has been fulfilled by benefiting from other data sources (e.g. Dartmouth, literature...).

In conclusion, suggestions and implication for nonstandardized national databases, TABB could be sum up as;

- As a government office and only publicly accessible disaster data source for Turkey, TABB and AFAD could collect high quality data and produce related publications regularly.

- During computing processes of disaster data, attention should be paid on accuracy of data and data quality controls.

- Disaster database should be presented as classified according to a globally accepted disaster classification system. In terms of standardization, methodology and definitions should explain clearly.

- Most of the loss parameters in TABB (e.g. number of damaged building, total missing, displaced, total damage...) are incomplete.

- To make TABB more useful and sharable, interlanguage version should be developed as well.
Loss data collection is gaining more and more attention, e.g. in the Sendai Framework for Disaster Risk Reduction 2015-2030 (SFDRR) [28] and the loss and damage program of the UNFCCC (United Nations Framework Convention on Climate Change). Correspondingly, the study could offer a base-work for developing guidelines and procedures on how to standardize loss databases and implement across the other hazard events to monitor progress of (flood) risk mitigation and adaptation in Turkey.

Acknowledgment: This study has been undertaken as part of the "ITN - ALErT: Anatolian pLateau climatE and Tectonic hazards" Project, funded within the EU Marie Curie Actions program "Initial Training Networks (ITN)" under grand agreement FP7-PEOPLE-2013-ITN (no. 607996).

\section{References}

1. Genç, F.S., (2007). Türkiye'de Kentleşme ve Doğal Afet Riskleri ile İlişkisi, TMMOB Afet Sempozyumu (available at imo.org.tr).

2. Gürer, I. and Uçar, I. (2009). Flood disasters' inventory in Turkey in 2009. In International Symposium on Water Management and Hydraulic Engineering, (pp. 1-5).

3. Özcan, E. (2006). Sel olay1 ve Türkiye. Gazi Üniversitesi Gazi Eğitim Fakültesi Dergisi, 26(1).

4. Beyhun, E.N., Altintaş, K. M. H. and Noji, E. C. (2005). Analysis of registered floods in Turkey. International Journal of Disaster Medicine, 3(1-4), 50-54.

5. Ceylan, A., Alan, I. and Ugurlu, A. (2007). Causes and effects of flood hazards in Turkey. In International Congress of River Basin Management (pp. 22-24).

6. Kömüşcü, A. Ü. and Çelik, S. (2013). Analysis of the Marmara flood in Turkey, 7-10 September 2009: an assessment from hydrometeorological perspective. Natural hazards, 66(2), 781-808.

7. Yüksek, Ö., Kankal, M. and Üçüncü, O. (2013). Assessment of big floods in the Eastern Black Sea Basin of Turkey. Environmental monitoring and assessment, 185(1), 797-814.

8. Gül, G. O. (2013). Estimating flood exposure potentials in Turkish catchments through indexbased flood mapping. Natural hazards, 69(1), 403423.

9. Citiroglu, H. K. and Baysal, G. (2011). Effects of geological and hydrological factors on the creation of flooding in Kozlu, Zonguldak, NW Turkey. International Journal of Physical Sciences, 6(6), 1360-1373. 
10. Ataman, O. and Tabban, A. (1977). Türkiye'de Yerleşme Alanlarının Doğal Afetler İle İlişkileri. Mimarlık Dergisi, 153, 25-27.

11. IRDR (2014), IRDR Peril Classification and Hazard Glossary. Report of the Data Group in the Integrated Research on Disaster Risk. (available at: http://www.irdrinternational.org/2014/03/28/irdrperil-classification-and-hazard-glossary).

12. URL: $\underline{w w w . e m d a t . b e}$

13. Gall, M., Borden, K. A. and Cutter, S. L. (2009). When do losses count? Bulletin of the American Meteorological Society, 90(6), 799.

14. TВMM (2010), Deprem Riskinin Araştırllarak Deprem Yönetiminde Alınması Gereken Önlemlerin Belirlenmesi Amacıla Kurulan Meclis Araştırması Komisyonu Raporu. Temmuz, 2010.

15. Özmen, B. (2000), 17 Ağustos 1999 İzmit Körfezi Depreminin Hasar Durumu (Rakamsal Verilerle), TDV/DR 010-53, Türkiye Deprem Vakfi, 132 s.

16. USGS (2000), USGS Earthquake Hazards Program: Earthquake Report: TURKEY (available at : http://web.archive.org/web/20120308105107/http://n eic.usgs.gov/neis/eq depot/1999/eq 990817/).

17. URL : www.deprem.gov.tr/en/Category/nationalearthquake-research-programm-34501

18. URL : www.afad.gov.tr

19. URL : tabb.afad.gov.tr

20. Llasat, M. C., Llasat-Botija, M., Petrucci, O., Pasqua, A. A., Rosselló, J., Vinet, F. and Boissier, L. (2013). Towards a database on societal impact of Mediterranean floods within the framework of the HYMEX project. Natural Hazards and Earth System Science, 13(5), 1337-1350.

21. Jha, M. K. (Ed.). (2010). Natural and Anthropogenic Disasters: vulnerability, preparedness and mitigation. Springer Science \& Business Media.

22. Guha-Sapir, D. and Below, R. (2002). The quality and accuracy of disaster data: a comparative analyses of three global data sets. World Bank, Disaster Management Facility, ProVention Consortium.

23. Arman, H., Yuksel, I., Saltabas, L., Goktepe, F. and Sandalci, M. (2010). Overview of flooding damages and its destructions: a case study of ZonguldakBartin basin in Turkey. Natural Science, 2(04), 409.
24. URL : http://www.tcmb.gov.tr/wps/wcm/connect/tcm $\mathrm{b}+\mathrm{en} / \mathrm{tcmb}+\mathrm{en} / \mathrm{main}+\mathrm{menu} / \mathrm{statistics} /$ exchange + rates/ indicative + exchange+rates

25. URL:http://evds.tcmb.gov.tr/cgibin/famecgi?cgi $=\$$ ozetweb $\& D I L=U K \& A R A V E R I G$ $\underline{\text { RUP=bie dkdovizgn.db }}$

26. URL :tr.wikipedia.org/wiki/Sar $\% \mathrm{C} 4 \% \mathrm{~B} 1 \mathrm{kam} \% \mathrm{C} 4 \%$ B1\%C5\%9F

27. Merz, B., Kreibich, H., Schwarze, R. and Thieken, A. (2010). Review article" Assessment of economic flood damage". Natural Hazards and Earth System Sciences, 10(8), 1697-1724.

28. UNISDR/GE (2015), Sendai Framework for Disaster Risk Reduction 2015-2030. (Available at: http://www.preventionweb.net/files/43291_sendaifra meworkfordrren.pdf).

29. Global Active Archive of Large Flood Events Dartmouth Flood Observatory (available at: floodobservatory.colorado.edu)

\section{Related References for Annex 2:}

- Aksoy, B, and Coskun, M., (2010). Aksu Vadisi Giresun) Aşaği Kesiminde Doğal Ortam Şartlarinin Taşkin Üzerine Etkileri. Gazi Türkiyat Türkoloji Araştırmaları Dergisi, 1(7).

- $\quad$ Altundal, M. (2010). Taskinlarin Ekonomik Boyutu. 2. Ulusal Taşkin Sempozyumu Panel Sunulari ve Tebliğler Kitabi (22-24 Mart 2010).

- Avci, V. and Sunkar, M. (2015). Giresun'da Sel ve Taşkin Oluşumuna Neden Olan Aksu Çayi ve Batlama Deresi Havzalarinin Morfometrik Analizleri. Coğrafya Dergisi, (30), 91-119.

- Avsar, E. (2014). Ege Bölgesi’ nde Meydana Gelen Şiddetli Yağişlarin Analizi ve Etkileri, Technical Report, DOI:10.13140/RG.2.1.1505.4246. (available at:https://www.researchgate.net/publication/2760594 63 EGE BLGES NDE MEYDANA GELEN DD ETL YAILARIN ANALZ VE ETKLER\#full-text)

- Bahadir, M. (2014). Samsun'da Meydana Gelen 4 Temmuz ve 6 Ağustos 2012 Taşkinlarinin Klimatik Analizi. Coğrafya Dergisi, (29), 28-50.

- $\quad$ Buldur, A. D., Pınar, A. and Başaran, A. (2007). 0507 Mart 2004 Tarihli Göksu Nehri Taşkını ve Silifke'ye Etkisi. Selçuk Üniversitesi Sosyal Bilimler Enstitüsü Dergisi, 17, 139-160. 
- Ergünay, O. (2007). Türkiye'nin afet profili. TMMOB Afet Sempozyumu Bildiriler Kitabı, 5-7.

- Ertek, T. A. (1995). Senirkent Seli (13 Temmuz 1995-Isparta). Türk Coğrafya Dergisi, (30).

- Gurgen, G. (2004). Doğu Karadeniz Bölümünde Maksimum Yağışlar ve Taşkınlar Açısından Önemi. Gazi Eğitim Fakültesi Dergisi, 24(2).

- Gürer, I. (1998). Flood Disasters and Preventative Measures in Turkey. Journal of natural disaster science, 20(1), 1-9.

- Kadığlu, M. (2012). Türkiye'de İklim Değişikliği Risk Yönetimi. Turkiye'nin İklim Değiş̧ikliği II. Ulusal Bildiriminin Hazırlanması Projesi Yayını, 172.

- Kocman, A. and Kayan, İ. (1996), İzmir'de 3-4 Kasım 1995 Karşıyaka Sel Felaketi (Oluşumu gelişimi, etkileri ve alınması gereken önlemler). Araştırma Raporu. E.Ü. İmir Araştırma ve Uygulama Merkezi yayını $\mathbf{1}$.

- $\quad$ Kömüşçü, A. Ü., Çelik, S. and Ceylan, A. (2011). 812 Eylül 2009 Tarihlerinde Marmara Bölgesi'nde Meydana Gelen Sel Olayının Yağış Analizi. Coğrafi Bilimler Dergisi. In CBD (Vol. 9, No. 2, pp. 209220).

- Mutluer, M. and Isik, S., (2000). The Observations About the Works After Karsiyaka-Cigli Flood Disaster on November 1995, Aegean Geographical Journal, 11 (2000), 57-74.

- Onsoy, H. (2011). Yaz Taşkin Periyodu ve Bölgesel $\mathrm{Su}$ Konseyi (available at : www.supolitikalaridernegi.org/yaz-taskin-periyoduve-bolgesel-su-konseyi).

- Ozden, A.T. (2004). Evaluation of Post-Disaster Housing in Senirkent, Thesis (M.Sc.), Istanbul Technical University, Institute of Science and Technology,(available at:hdl.handle.net/11527/8470).

- Özden, Ş., Gökçe, O., Demir, A. and Çiftçi, A. (2008). Türkiye'deki Su Baskinlari Zamansal Mekansal Dagilimi, Afet Bilgi Envanter Projesi. Kar Hidrolojisi Konferansi.
- $\quad$ Reis, S., Atasoy, M., Nişancı, R., Yalçın, A., Bayrak, T., Sancar, C. and İnan, H. (2007). Doğal Afetlere Yönelik Konumsal Veritabani Oluşturulmasi: Rize İli Örneği, TMMOB Harita ve Kadastro Mühendisleri Odası 11. Türkiye Harita Bilimsel ve Teknik Kurultayı, 2-6 Nisan 2007, Ankara.

- Sezer, L. İ. (1997). İzmir'de 34 Kasım 1995 Karşıyaka-Çiğli Sel Felaketi (MeteorolojikKlimatolojik Açıdan Bir Yaklaşım). Ege Coğrafya Dergisi, 9(1).

- Şahin, K. (2002). Çarşamba Ovası ve yakın çevresinde sel afeti (27 Mayıs 2000). Türk Coğrafya Dergisi, (39).

- Şahinalp, M. S. (2007). Neden ve sonuçlariyla Şanlıurfa İlinde yaşanan sel felaketleri (28-29 Ekim, 01 Kasım 2006). Türk Coğrafya Dergisi, (49).

- T.C. Çevre ve Orman Bakanliği Devlet Su İşleri Genel Müdürlüğü XXII. Bölge Müdürlüğü (2008). 5. Dünya Su Forumu Türkiye Bölgesel Hazirlik Toplantilari Taşkin, Heyelan ve Dere Yataklarinin Korunmasi Konferansi Bildiri Kitabı, 7-8 Agustos, 2008

- Tonbul, S. and Sunkar, M. (2011). Batman'da yaşanan Sel ve taşkın olaylarının (31 Ekim-1 Kasım 2006) Sebep ve Sonuçları. Fiziki Coğrafya Araştırmalarl, 237-258, (available at: scholar.googleusercontent.com/scholar?q=cache:zUk MBluVIMMJ:scholar.google.com/+2006+batman+se $\underline{1+\text { olayi\&hl }=\text { de\&as } \mathrm{sdt}=0,5)}$.

- Turoglu, H. (2011). İstanbul'da Meydana Gelen Sel ve Taşkınlar, Fiziki Coğrafya Araştırmaları; Sistematik ve Bölgesel, Türk Coğrafya Китити Yayınları, No:5, 411-430.

- Türkoğlu, N. (2009). Analysis of floods occured on October 31-November 1, 2006 in Southeast Anatolia regyon. Nature Sciences, 4(4), 243-254.

- Yurt, R. Doğu Karadeniz Bölümü Doğal Afet Planlarının Hazırlanması (available at : tucaum.ankara.edu.tr/wpcontent/uploads/sites/280/2015/08/semp7_2.pdf).

- Zeybek, İ. (1998). 22 Mayıs 1998 Havza Sel-Taşkın Felaketi. Ondokuz Mayıs Üniversitesi Eğitim Fakültesi Dergisi, 11(1), 160-167. 
- Anonymous, Afet Müdahale ve Yardim Müdürlüğü 2004 Yili Faaliyet Raporu (available at: afetyonetimi.kizilay.org.tr/UI/doc/raporlar/2004.pdf).

- $\quad$ Anonymous, Afet Koordinasyon Merkezi, 21 Mayis - 27 Mayis 2007 Türkiye'de ve Dünya'da Meydana Gelen Afetler (available at: http://www.ibb.gov.tr/sites/akom/documents/afet_bul teni_2007_21.html)

- Anonymous, (2011), Afetler ve Afet Yönetimi (available at: http://www.dsi.gov.tr/docs/sempozyumlar/2-6giresun'da-afet-y\%C3\%B6netimi---mustafasezer.pdf?sfvrsn=2)

- Anonymous, (2003). Selin Bilançosu: 5 Ölü, 33 Trilyon Lira (News Agency Report, Antalya - Kanal vip 29 Arallk 2003, Pazartesi 00:00) (available at: http://bianet.org/bianet/siyaset/28058-selinbilancosu-5-olu-33-trilyon-lira).

- URL:https://tr.wikipedia.org/wiki/2009_Marmara_se 1 dizisi

- URL:http://webarsiv.hurriyet.com.tr/2005/09/03/696 161.asp 


\section{ANNEX 1}

\section{TURKEY DISASTER DATABASE (TABB) LOSS PARAMETERS}

Effected Areas

Total Death

Total Injured

Total Missing

Number of Destroyed Building

Number of Damaged Building

Affected

Displaced

Evacuated

Total Damage (\$)

Total Damage (TL)

Destroyed Agricultural Area (Ha)

Cattle Loss

GLIDE NO

Condition

Deaths (child 0-18)

Deaths (adult +18 )

Deaths (female)

Deaths (male)
Injured (child 0-18)

Injured (adult +18 )

Injured (female)

Injured (male)

Non-damaged public buildings

Light damaged public buildings

Moderate damaged public buildings

Heavy damaged public buildings

Run-downed public buildings

Non-damaged residence buildings

Light damaged residence buildings

Moderate damaged residence buildings

Heavy damaged residence buildings

Run-downed residence buildings

Non-damaged workplace buildings

Light damaged workplace buildings

Moderate damaged workplace buildings

Heavy damaged workplace buildings

Run-downed workplace buildings 


\section{ANNEX 2}

\section{MOST SEVERE FLOOD EVENTS IN TURKEY}

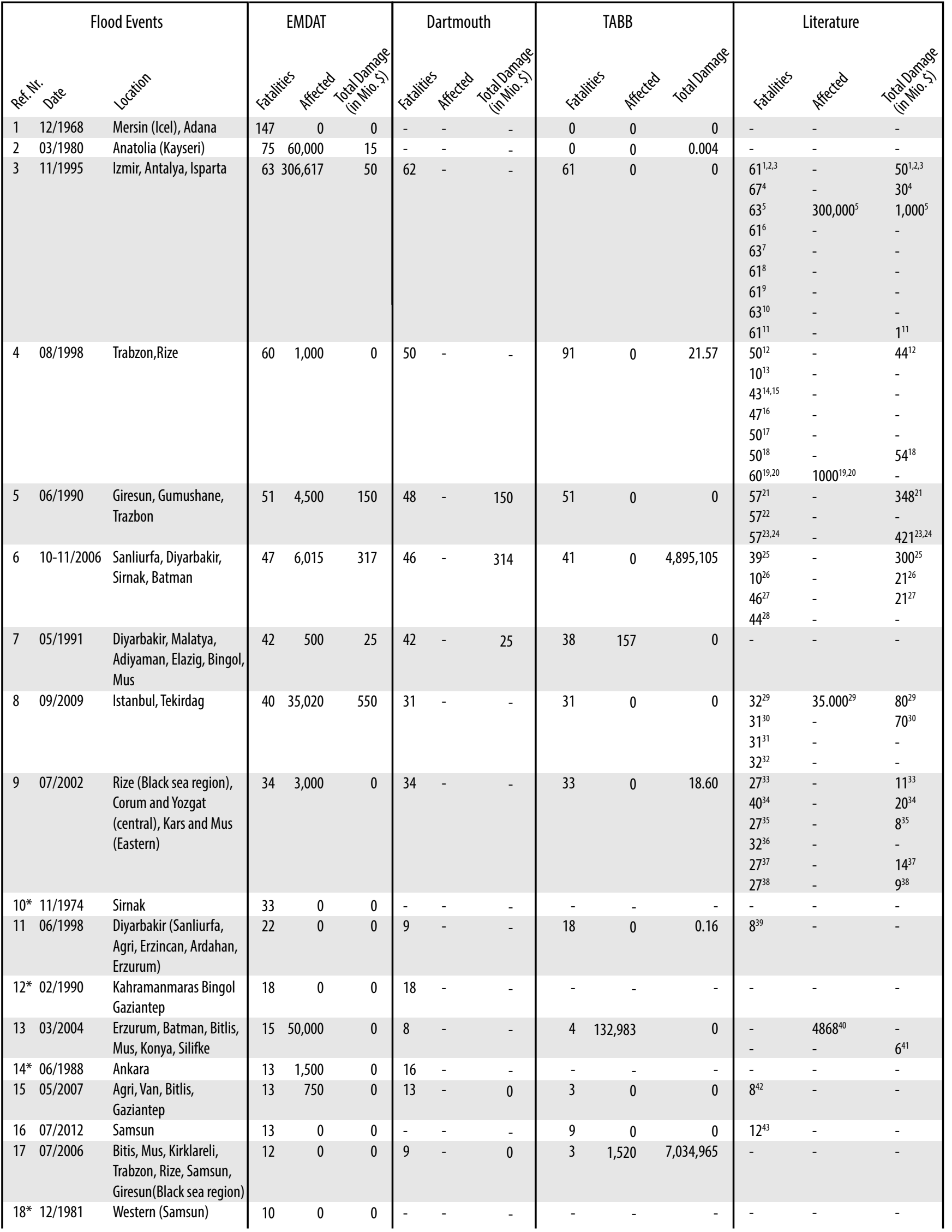




\section{MOST SEVERE FLOOD EVENTS IN TURKEY}

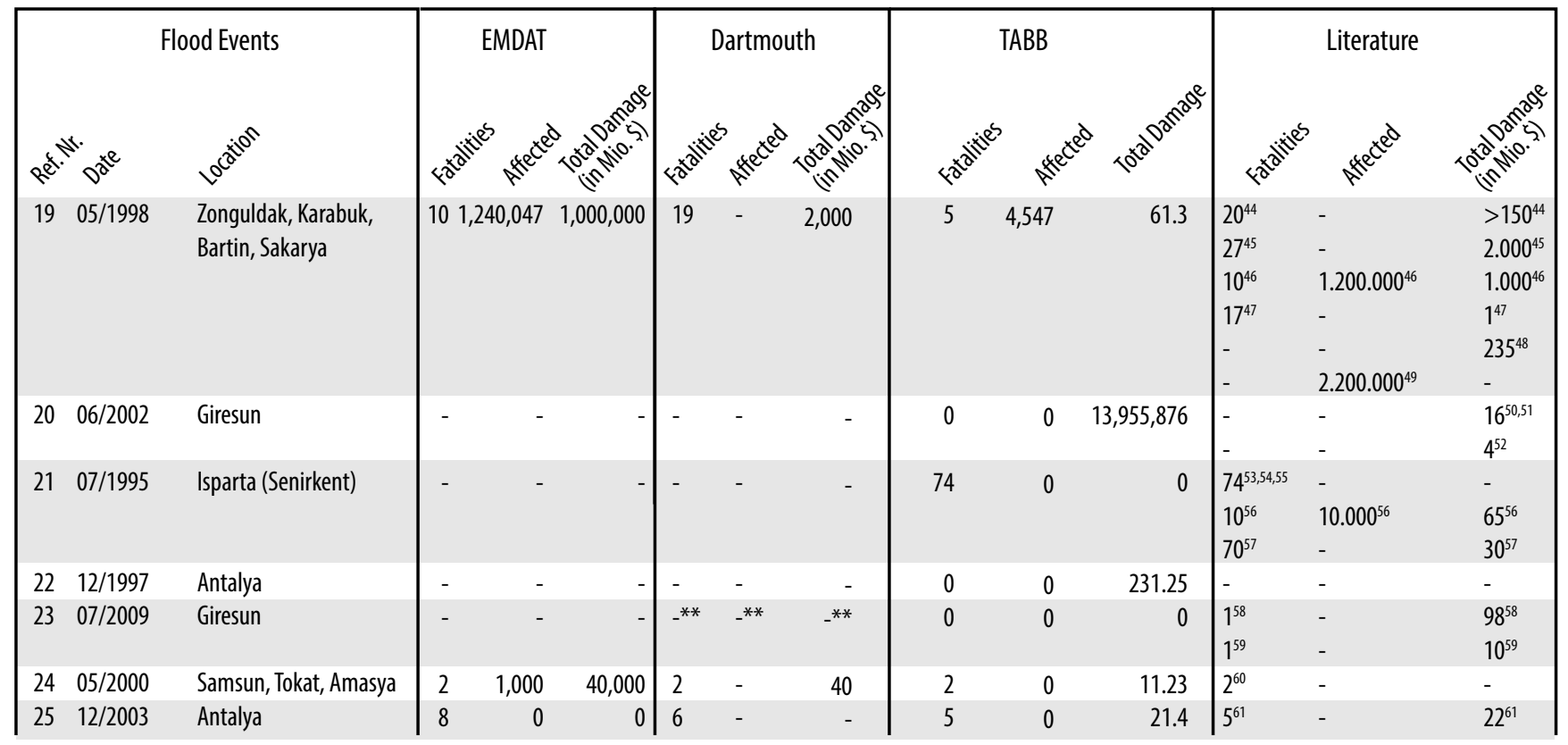

*Only in EMDAT and/or Darthmouth database

** This event is also in Darthmouth database but no information about fatalities, affected people or economic loss.

${ }^{1}$ Kömüşcü \& Çelik (2013)

${ }^{2}$ Ceylan et al.(2007)

${ }^{3}$ Avsar (2014)

${ }^{4}$ Gürer (1998)

${ }^{5}$ Ergünay (2007)

${ }^{6}$ Kocman et al. (1996)

${ }^{7}$ Sezer (1997)

${ }^{8}$ Mutluer \& Isik (2000)

${ }^{9}$ Zeybek (1998)

${ }^{10}$ Altundal (2010)

${ }^{11}$ Kadioglu (2012)

${ }^{12}$ Yüksek et al. (2013)

${ }^{13}$ Ceylan et al. (2007)

${ }^{14}$ Gürgen (2004)

${ }^{15}$ Yurt (2012)

${ }^{16}$ Sahin (2002)

${ }^{17}$ webarsiv.hurriyet.com.tr/2005/09/03/696161.asp

${ }^{18}$ T.C. Çevre ve Orman Bakanliği (2008)

${ }^{19}$ Anonymous (2011)

${ }^{20}$ Altundal (2010)

${ }^{21}$ Yüksek et al. (2013)

${ }^{22}$ Gürgen (2004)

${ }^{23}$ T.C. Çevre ve Orman Bakanliği (2008)

${ }^{24}$ Avci \& Sunkar (2015)

${ }^{25}$ Gürer \& Uçar (2009)

${ }^{26}$ Tonbul \& Sunkar $(2011)^{* * *}$

${ }^{27}$ Şahinalp (2007)

${ }^{28}$ Türkoğlu (2009)

${ }^{29}$ Kömüşcü \& Çelik (2013)

${ }^{30}$ tr.wikipedia.org/wiki/2009_Marmara_sel_dizisi

${ }^{31}$ Turoglu (2011)

${ }^{32}$ Kömüşcü et al. (2009)

${ }^{33}$ Yüksek et al. (2013)

${ }^{34}$ Ceylan et al. (2007)
${ }^{35}$ Gürer \& Uçar (2009)

${ }^{36}$ webarsiv.hurriyet.com.tr/2005/09/03/696161.asp

${ }^{37}$ T.C. Çevre ve Orman Bakanliği (2008)

${ }^{38}$ Reis et al. (2007)****

${ }^{39}$ Ceylan et al. (2007)

${ }^{40}$ Anonymous (2004)

${ }^{41}$ Buldur et al. (2007)

${ }^{42}$ Anonymous (2007)

${ }^{43}$ Bahadir (2014)

${ }^{44}$ Kömüşcü \& Çelik (2013)

${ }^{45}$ Ceylan et al. (2007)

${ }^{46}$ Ergünay (2007)

${ }^{47}$ Zeybek (1998)

${ }^{48}$ Altundal (2010)

${ }^{49}$ Kadioglu (2012)

${ }^{50}$ Avci \& Sunkar (2015)

${ }^{51}$ Anonymous (2011)

${ }^{52}$ Aksoy \& Coskun (2010)

${ }^{53}$ Özden (2004)

${ }^{54}$ Zeybek (1998)

${ }^{55}$ Ertek (1995)

${ }^{56}$ Altundal (2010)

${ }^{57}$ Ceylan et al. (2007)

${ }^{58}$ Avci \& Sunkar (2015)

${ }^{59}$ Onsoy (2011)

${ }^{60}$ Ceylan et al. (2007), [13]

${ }^{61}$ Anonymous (2003)

*** This information is only for Batman province

****This information is only for Rize province 